\title{
An Unintended Legacy: The External Policy Responses of the USA and European Union to Conflict Minerals in Africa
}

\author{
Michael Addaney ${ }^{1,2, *(\mathbb{D})}$ and Emma Charlene Lubaale ${ }^{3}$ (D) \\ 1 Department of Planning and Sustainability, School of Geosciences, University of Energy and Natural \\ Resources, Sunyani, Ghana \\ 2 Centre for Public Management and Governance, School of Public Management, Governance and Public \\ Policy, University of Johannesburg, Johannesburg 2193, South Africa \\ 3 Faculty of Law, Rhodes University, Grahamstown 6139, South Africa; e.lubaale@ru.ac.za \\ * Correspondence: michael.addaney@uenr.edu.gh
}

check for updates

Citation: Addaney, Michael, and Emma Charlene Lubaale. 2021. An Unintended Legacy: The External Policy Responses of the USA and European Union to Conflict Minerals in Africa. Laws 10: 50. https:// doi.org/10.3390/laws10020050

Received: 15 May 2021

Accepted: 15 June 2021

Published: 17 June 2021

Publisher's Note: MDPI stays neutral with regard to jurisdictional claims in published maps and institutional affiliations.

Copyright: (C) 2021 by the authors. Licensee MDPI, Basel, Switzerland. This article is an open access article distributed under the terms and conditions of the Creative Commons Attribution (CC BY) license (https:// creativecommons.org/licenses/by/ $4.0 /)$.

\begin{abstract}
Competition over environmental and natural resources characteristically lies at the heart of armed conflicts in Africa. It is also common knowledge that some companies dealing in products such as laptops, smart phones, and jewellery import minerals from conflict-affected areas, thereby indirectly fuelling conflicts in these areas or undermining human rights. For a continent endowed with natural resources including minerals, Africa has suffered the brunt of this predicament. This state of affairs has lent impetus to the adoption of several regulations geared towards curbing irresponsible business practices by companies relying on such minerals, the goal being, amongst others, to guarantee the protection of human rights. In May 2017, the European Union adopted regulations intended to stop the importation of conflict minerals in Europe, debatably making giant strides in the direction of the protection of human rights. These regulations are to come into force in 2021. However, can these regulations advance the much-desired goal of the protection of human rights in Africa on issues pertaining to conflict minerals? By analyzing the 2017 EU regulations in light of previous regulations of a similar nature, the paper concludes that the said regulations constitute a weak normative framework and could in fact have unintended consequences on the fundamental rights of civilians in natural resource-rich conflict areas of Africa.
\end{abstract}

Keywords: Africa; armed conflict; business; corporations; environment; human rights; minerals; European Union; regulations

\section{Introduction}

The abundance of natural resources across African countries is indisputable. Natural resources, in this regard, range from minerals such as gold and diamond to oil, water and timber. Properly utilized and exploited, these resources play a critical role in the development of economies, and indeed, many African countries rely heavily on natural resources for their exports. Notable are countries such as Botswana, which have leveraged mineral resources to build a sustainable economy (Bannon and Collier 2003). Ironically, however, while natural resources ought to be a 'blessing' and in fact used to ease countries' financial burden, they have turned out to be a 'resource curse' ${ }^{1}$ in many countries across Africa (Ross 2003, p. 17). This is particularly the case in conflict-affected areas. Studies show that there could be a link between natural resources and armed conflict (Beevers 2018; Berman and Couttenier 2015; Murshed 2014). Within the particular context of developing countries, including those in Africa, reports reveal that economies endowed with natural

1 This concept was first used by the economist Richard Auty in his seminal 1993 seminal work titled Sustaining Development in Mineral Economies: The Resource Curse Thesis. The notion, in its original sense, implies the 'paradox of plenty' where otherwise mineral-rich countries have nothing to show for it because these resources often trigger conflict or hardly contribute to the well-being of societies. The notion has been used in subsequent literature including (Ross 2003, p. 17). 
resources are at a particularly high risk of armed conflict (Murshed 2014; Bannon and Collier 2003). Of note, the dynamics of armed conflict are complicated and cannot simplistically be explained by narratives of abundance of natural resources. Often, there are several underlying issues at play, including poverty and religious or ethnic grievances. This makes conflict a multi-faceted issue. This caveat notwithstanding, studies have also consistently illustrated that natural resources may trigger or prolong armed conflicts (Beevers 2018; Murshed 2014). As most armed groups do not have reliable and consistent sources of funding, recourse to natural resources has become inevitable to enable them to fund their activities (Bannon and Collier 2003; Partzsch 2018).

The process of mineral exploitation in conflict situations is a multi-faceted one, with armed groups never operating in a vacuum. These minerals are typically exported from developing countries (including those in Africa) and used for the production of finished products in developed countries in the West. Palou (2010, p. 14) describes this dynamic as a vicious cycle in which both non-state actors and state actors consistently feed the cycle of conflict. The role of non-state actors such as business corporations comes into play based on their reliance on natural resources obtained from armed groups in conflict-affected areas to manufacture products. It is a known fact that various finished products including jewellery and electronics require minerals as raw materials. The Democratic Republic of the Congo (DRC), for example, a country where conflict mineral activity is well documented, is one of the leading suppliers of tin (Coakley 2000). Tin is used for producing various products including circuit boards for various electronic gadgets (Prendergast and Lezhnev 2009; Fitzpatrick et al. 2015). The DRC also manufactures tantalum (Coakley 2000), a mineral found in a wide range of products including digital cameras, cell phones and portable music players (Prendergast and Lezhnev 2009). Reports (e.g., Rahima et al. 2016; Henriksson and Rivera 2014) indicate that the demand for these products is on the increase and so is the demand for the minerals required to produce them.

What is especially unfortunate is that many of the minerals used in manufacturing these products are mined under situations of conflict and human rights violations (Nanda 2014). It is documented that a full spectrum of human and environmental rights are violated during conflict and mining processes (Arimatsu and Mistry 2012; Nanda 2014). In these situations, for example, children have become major targets, being subjected to child labour and recruited to serve as child soldiers (O'Driscoll 2017). Rape, murder, and other forms of violence against the civilian population are pervasive (Brown 2011; Maedl 2011; Human Rights Watch 2018). The illegality surrounding the process of mining minerals in situations of conflict leaves little to no regard for environmental impact assessment and workers' rights (Institute for Environmental Security 2008). As a result, pollution of the air, soil and water remains prevalent (Addaney et al. 2019). The land rights of the civilian population are also threatened by these activities, as communities are usually forcefully evicted to give way to mining activities (Amnesty International 2013).

The narrative is inexhaustible but considered together, by relying on minerals from these situations, business corporations have indirectly been conduits of human rights violations and armed conflicts. With innumerable individuals across the globe relying on products benefiting from these minerals, the issue of conflict minerals is one of global concern. Not coincidentally, various countries outside Africa have shared in the responsibility to address this challenge by embarking on various initiatives. Notable amongst these is the United States of America's (USA's) prominent Section 1502 (Dodd-Frank Act 2010, sct. 1502). This section focuses, amongst others, on disclosure of the source of their minerals on the part of business corporations. The idea is that such disclosure would ensure transparency as far as the source of minerals for products is concerned, and ultimately, this would help address the challenge of conflict minerals through responsible trading. 
In 2017, drawing on the pace set by the USA, the European Union adopted regulations ${ }^{2}$ intended to stop the importation of conflict minerals in Europe, debatably making giant strides in the direction of the protection of human rights. These regulations are to come into force in 2021. However, a question remains of whether these regulations can advance the much-anticipated goal of protecting human and environmental rights in Africa on issues pertaining to conflict minerals.

This article, therefore, analyses the $2017 \mathrm{EU}$ regulations in light of previous regulations of a similar nature such as the USA's Section 1502. In conducting this analysis, the article assesses whether these regulations constitute a strong normative framework to advance the much-desired goal of the protection of human rights in Africa on issues pertaining to conflict minerals. The article is divided into four parts. Subsequent to this background, the second section places the discussion into context by providing a description of conflict minerals in the context of the DRC and Sierra Leone. This section shows how the issue of conflict minerals has played out in these two countries, the role of business corporations in this scheme of events and the human and environmental rights that are or were at stake. This section sets the stage for the third section, which critically analyses the EU initiative to address the challenges resulting from conflict minerals. The third section assesses the EU regulations in addressing this challenge, ultimately answering the question of whether they constitute a strong, comprehensive, and effective tool for addressing this challenge.

\section{Bringing the Challenge of Conflict Minerals Closer to Home: Historical Perspectives of Conflict Minerals in Africa}

This section examines international efforts to address conflict minerals in the DR Congo and surrounding countries. The DR Congo and other countries in the Great Lakes are illustrative because the conflict in eastern DR Congo is widely observed to be linked to natural resources and, consequently, is the target of substantial international intervention. This section argues that lessons should be learned from the blood diamonds industry as the international community and global powers confront the realities of conflict minerals in the DR Congo and surrounding countries. As argued by Beevers (2018), some of the interventions in conflict mineral countries being promoted by international actors and foreign governments have made sustainable development more challenging because they foster contention in at least three ways: recreating historical governance arrangements, overlooking the environment and sustainable livelihoods, and creating unrealistic expectations. Although the question of blood diamonds is by no means resolved, the international and regional efforts made to restructure the international diamond industry have some inherent strong points and flaws that can be gleaned on as efforts are being made to find durable approaches to regulate the international sale and trade in conflict minerals (Raj 2011). The spotlight on the DR Congo and surrounding countries has helped to underscore the role that gold, diamonds, and other resources can potentially play in fueling conflict. It also has provided a sound rationale for international actors to improve natural-resource governance and help protect human rights. There certainly have been many positives to international intervention, but a closer look reveals that any progress has been offset by mounting problems that are fundamentally analogous in both countries. For instance, gains in human development have been modest in the country, thus undermining the enjoyment of human rights such as adequate water, food, shelter, and sanitation of vulnerable populations. Put simply, efforts to improve natural-resource governance have yet to result in the cessation of armed conflict as well as improved livelihoods or appreciable development outcomes in the eastern part of the DR Congo.

The DR Congo, situated at the heart of Africa, has been mentioned as the home of the deadliest war in the world after World War II as well as being the theatre for Africa's

2 Regulation (EU) 2017/821 of the European Parliament and of the Council of 17 May 2017 laying down supply chain due diligence obligations for Union importers of tin, tantalum and tungsten, their ores, and gold originating from conflict-affected and high-risk areas. See text of these Regulations at https:/ / eur-lex.europa.eu/legal-content/EN/TXT/PDF/?uri=CELEX:32017R0821\&from=EN (European Parliament and of the Council 2017) (accessed on 12 May 2021). 
deadliest conflict in recorded history (International Rescue Commission 2002). Autesserre (2008) has described the situation in the DR Congo as the leading humanitarian crisis on earth. The civil war officially ended in 2002 after a peace agreement laid the foundation for a transitional government (Davis and Hayner 2009). Conversely, the humanitarian crisis continues unabated, with a projected death toll of 45,000 people monthly due to the consequences of the ongoing conflict (Davis and Hayner 2009). It was reported that from the beginning of the conflict in August 1998 to April 2007, an estimated 5.4 million people died from this conflict (Benjamin Coghlan et al. 2007). The ongoing conflict raging in the DR Congo is irrefutably complex. Similarly, it is incontrovertible that the multimilliondollar international sale and trade in minerals is one of the fundamental issues driving the conflict and the resultant humanitarian catastrophe (The Enough Project and Grassroots Reconciliation Group 2009). The DR Congo, even though it is one of the most impoverished countries on earth, has mineral reserves estimated to be worth $\$ 24$ trillion (UN 2011). The ongoing conflict is concentrated largely in the eastern DR Congo provinces of North Kivu, South Kivu, and Orientale-arguably, the provinces hosting some of the greatest mineral wealth in the country (UN 2011). These three provinces remain largely in the control of rebel militias and are out of the central government's control (Davis and Hayner 2009).

Despite its numerous underlying causes, one of the dominant factors fueling the conflict is that the different warring groups are seeking to acquire and sustain power through controlling the mineral resources and mines (Davis and Hayner 2009). While the original conflict did not start due to mineral wealth, the international sale and trade of minerals has been sustaining armed combatants and thus fuels ongoing atrocities (Prendergast and Atama 2009). The specific minerals at stake in the ongoing conflict are tin (cassiterite), tantalum (coltan or columbite-tantalite), tungsten (wolframite), and gold (3TG). Conflict minerals are broadly defined to include 'columbite-tantalite (coltan), cassiterite, gold, wolframite, or their derivatives', along with any other mineral or derivative that finance conflict in the DRC. ${ }^{3}$ These minerals are extremely valuable metals after they are processed. For instance, tin is used for the production of solder on circuit boards (Prendergast 2009). Considering the number of electronics that use circuit boards, it is easy to grasp the significant role tin plays in the industry. Similarly, tantalum is used in cell phones, digital cameras, and iPods for storing electricity in capacitors, whereas tungsten is used for making cell phones that vibrate (Prendergast 2009). The final conflict mineral, gold, is normally used in the production of electronics. Gold is a key source of revenue in the DR Congo, with armed groups reportedly netting between $\$ 44$ and $\$ 88$ million annually from the sale of gold alone (Prendergast 2009).

In the past few decades, there has been increased concerns about 'conflict minerals', especially referring to electronics made with minerals mined in the DR Congo. These headlines were allegedly indicative of ongoing concerns dating a few years back regarding trade in 'blood diamonds', or 'clouded diamonds' (Murphy 2010). Rebel groups across the African continent are known to be using the proceeds from trading in these minerals to fund armed conflicts and undermine legitimate governments in the major trouble areas such as the DR Congo, Angola, and Sierra Leone. This reality illustrates what has been termed as the 'resource curse', a situation where a poor country's natural resource abundance leads to problems such as poor governance, corruption, and nepotism. Heightened international awareness of this grave problem and public pressures coupled with efforts to find a durable solution led to the adoption of the Kimberley Process Certification Scheme (KPCS) ${ }^{4}$ by 39 countries in 2002 with its implementation kicking off in 2003 (Fishman 2005). The Kimberley Process was developed at the end of the Sierra Leonean civil war as a mechanism to obliterate the financing of armed groups in Sierra Leone and Angola (UN Environment

3 The term 'conflict minerals' also refers to minerals coming from the Great Lakes Region, thus, eastern DR Congo, Rwanda, Burundi, and the Central African Republic. The term 'blood diamonds', a form of conflict mineral, is generally known; however, it is imperative to emphasize in this article that only minerals originating from DR Congo and surrounding countries are classified as 'conflict minerals'. See, (Kinzer 2015, pp. 89-105); Dodd-Frank Wall Street Reform and Consumer Protection Act, H.R. 4173, 111th Cong. \$1502 (e) (4) (2010).

4 The KPCS was introduced in 2000, but officially launched in 2003. See (Grant 2012). 
Programme 2010). The KPCS identifies conflict minerals and excludes them from legitimate trade. Conversely, due to its voluntary nature, the KPCS suffers from inherent challenges such as self-policing, poor monitoring and a lack of independent oversight, consensus decision-making, or administrative structure, leading to mixed results and severe criticism of the KPCS (Nichols 2012).

The trade in conflict minerals mined in the DR Congo and adjoining countries in the Great Lakes region of Africa has for some time been fueling armed conflicts in the region (Nanda 2014). The demand for products such as cell phones, laptops, appliances, and jewellery made from these minerals fuels this trade and funds the conflict. The international community and civil society groups have been actively pursuing durable means to end the international trade in conflict minerals originating from this region in Africa as proceeds from this trade are of the major elements responsible for the ongoing conflicts (Global Witness 2013). The minerals involved in the DR Congo conflict were observed by the US State Department in 2010 to include tungsten, tin, tantalum, and gold (U.S. Department of State 2010). It has further been noted that armed groups and military units in the eastern DR Congo use debt, intimidation, and physical violence to force villagers to extract these minerals from local mines (U.S. Department of State 2010). The money realized from the illicit sale and trade in these minerals are used in perpetuating the cycle of conflict, human trafficking, physical and sexual violence, and other human rights abuses.

Similar to the resource-driven armed conflict in the DR Congo, the armed conflicts in Liberia (1989 to 2003) and Sierra Leone (1991 to 2002) were driven by natural resources such as diamonds, iron ore, rubber, and timber. In particular, Charles Taylor, leader of the rebels in Liberia, controlled 90 percent of the country's territory by working with extractive companies to export millions of dollars of resources annually using large portions to buy weapons (Global Witness 2002; Keen 2005). In Sierra Leone, the Revolutionary United Front (RUF) instigated an insurrection by taking over the country's eastern mines and smuggled diamonds through Liberia in order to fund the revolt. The Sierra Leonean government equally depended on diamonds to finance the armed forces and hired mercenaries to reestablish government control in diamond mining areas. This practically warranted a hesitancy to end fighting since that would imply cutting off the steady stream of diamond revenue. International actors only started understanding the role of natural resources in the armed conflicts in Sierra Leone and Liberia in the late 1990s through reports by civil society groups (Smillie et al. 2000). Without a viable strategy to end the armed conflicts, the UN Security Council passed Resolution 1306 in July 2000, directing all countries to ban the direct or indirect importation of rough diamonds from Sierra Leone to cut down the flow of revenue to rebel groups (UN Security Council 2000). It also placed an obligation on the government to institute a certificate-of-origin requirement to ensure that exported diamonds did not originate from conflict areas. Among other factors, a reduction in the international sale of and revenue from diamonds led to the end of the armed conflict in Sierra Leone in 2002.

Being unable to secure diamonds from Sierra Leone, Charles Taylor focused on the timber industry in Liberia to fund the armed conflict (Global Witness 2002). Reports from civil society indicated that the timber industry plundered the country's forests and led to 'exacerbated sickness, hunger, poverty, and poor welfare' (Save My Future Foundation 2001, p. 7). The worsening security situation led the UN Security Council to pass Resolution 1478 in May 2003, requiring countries to stop the import of logs and timber products from Liberia (UN Security Council 2003). Charles Taylor left the country by October 2003, allowing UN peacekeepers to be deployed as well as the formation of a transitional government. The underlying causes of the armed conflicts in Liberia and Sierra Leone are complex, but the notion that natural resources fueled both is universal. For international actors, the central problem that needed to be addressed was the ability of rebel groups or corrupt government officials to loot resources and finance conflict (Altman et al. 2012). This demands ensuring that revenues from natural resources do not finance conflict; however, such interventions only slightly improve the conditions of miners and mining communities that live in debt 
and deep-rooted poverty (Beevers 2015). Thus, efforts to stifle the international sale and trading of minerals may reduce livelihood opportunities and renew resentment over the control of conflict minerals.

In the case of the DR Congo, the issue of conflict minerals rose into prominence as the 1994 Rwandan Genocide sparked chains of armed conflicts in the Great Lakes Region of Africa, leading to the deadliest war ever in Africa from 1998 to 2003. Although the war was primarily fought in the DR Congo, other countries such as Uganda and Rwanda were significantly involved. The control of mines became a great source of income for the various armed groups involved in the conflict, often using child slavery and rape as weapons to control local adversaries and local mines. From the DR Congo, these armed groups trafficked minerals to the east coast of Africa through the ports in Mombasa, Kenya or Dar es Salaam, Tanzania, where they are traded or exchanged for weapons to equip themselves to commit crimes against humanity (Kinzer 2015). From these ports, the minerals are dispatched to smelting companies in the USA, Europe, and Asia, where they are refined and mixed with other minerals from across the world and used for producing electronics. Conflict minerals can be found all over the world and thus, are easily replaceable in the international mineral trade (Kinzer 2015). Although the trade in conflict minerals has assumed an international issue, the USA is the sole country outside of the Great Lakes Region in Africa to adopt any legislation concerning conflict minerals.

The DR Congo, after the adoption of Section 1502 in the USA, barred the artisanal mining and export of tin, tantalum, and tungsten, excluding gold, in 2010 in order to eliminate the financing of armed groups in the eastern portion of the country (Tegera 2010). The ban was enforced unpredictably and was only applicable to the three provinces where conflict minerals were known to originate (Parker and Vadheim 2017). The government, however, lifted the mining and export ban after a few months in 2011 due to criticism concerning their effectiveness (Parker and Vadheim 2017). While national laws regulating conflict minerals are few, there are no international agreements regulating the practice apart from mechanisms originating from sub-regional bodies such as the International Conference on the Great Lakes Region. Thus, the KPCS framework governing the international sales and trading in diamonds as mentioned earlier serves as the only mechanism that broadly seeks to eradicate the funding of armed groups through the trafficking of blood diamonds across the world including the DR Congo (Human Rights Commission of Sierra Leone 2012). The KPSC obliges member countries to adopt domestic legislation to ban the import and export of rough diamonds to and from non-KP member countries. The objective of the KPSC is to end violent armed conflict. However, the basic challenge lies in ascertaining the connection between regulation of the trade in rough diamonds and a decrease in armed conflict in Sierra Leone. In other words, notwithstanding the fact that conflict minerals have become an international issue, there has been little effort to address conflict minerals as a matter of international law so far (Woody 2007).

The Organisation for Economic Co-Operation and Development's (OECD 2013) Due Diligence Guidance for Reasonable Supply Chains of Minerals from Conflict-Affected and High-Risk Areas (Due Diligence Guidance) offers a mutual set of expectations concerning responsible sourcing and strategies for responding to identified risks contributing to conflict or serious human rights abuses through sourcing practices (OECD 2013). The Due Diligence Guidance provides a separate appendage on tin, tantalum, and tungsten. Due to its multistakeholder nature, the Due Diligence Guidance involves the OECD, the United Nations, governments of the Great Lakes region of Africa, the international business community, as well as civil society representatives. It thus provides guidelines to companies that operate in or source minerals from conflict-affected and high-risk areas by helping them to avoid contributing to resource-fueled armed conflicts. The due diligence processes outlined in this mechanism provide that the supply chains of minerals must comply with the relevant international standards and applicable laws (OECD 2013). The Due Diligence Guidance further elucidates that the 
'nature and extent of due diligence that is appropriate will depend on individual circumstances and be affected by factors such as the size of the enterprise, the location of the activities, the situation in a particular country, and the sector and nature of the products or services involved'. (OECD 2013)

There is therefore an emerging consensus that the OECD Due Diligence Guidance should be used 'as a reference in terms of both relevant products and scope' in EU countries (Mitchell 2013). For instance, in September 2013, Karel De Gucht, European Trade Commissioner, observed that 'through a successful initiative on responsible sourcing, the EU would pursue measures to aid keeping money out of the hands of rebel groups.' He clarified that this would 'help in ensuring revenues from natural resources rather go to the government, strengthen the rule of law and consequently improve the provision of vital services such as health and education'. Other industry groups such as the World Gold Council have also adopted measures to fight the potential misuse of gold to finance armed conflicts (Shishmanian 2012). It established the Conflict-Free Gold Standard in October 2012 to provide a common strategy for gold producers to consider the means by which their gold has been extracted, and how to demonstrate that their gold is conflict-free (George 2013). The process comprises a commitment to adhere to human rights standards, transparency on payments to government officials, and procedures on reporting any breaches of the process to address grievances that local people might raise, with a yearly external assessment. Similarly, the Responsible Jewelry Council (RJC) has adopted a Code of Practice covering both gold and diamonds, which is an obligatory requirement for all its members. Through this mechanism, the RJC appraises 'gold, diamonds and platinum group metals companies from all parts of the supply chain, geographies, and size of business to find out how they can play their part in implementing responsible standards on the ground' (Long 2013). The discussions above are significant in combating the international sale and trading in conflict minerals as a study on mining sites in the eastern DR Congo showed that gold is the leading conflict mineral from the region'.

\section{The 2017 EU Regulations as a Framework to Address the Conflict Mineral Challenge: A Potential Game Changer?}

The above section has provided a general exposition of the challenges resulting from conflict minerals. The section has established that when business corporations across the globe benefit from conflict minerals, they indirectly fuel conflict in the affected countries and incidentally contribute to the violation of human rights. This is because armed groups rely on financial resources from business corporations to stay active in conflict and to continually perpetrate violence against the civilian population. The foregoing conclusion has been drawn from an analysis of the issue of conflict minerals in the context of the DRC, Sierra Leone, and surrounding countries. Against this backdrop, this section seeks to accomplish three tasks. First, it provides a brief exposition of selected initiatives adopted to address the challenges arising from recourse to conflict minerals. In providing this exposition, the section demonstrates that despite the paper's focus on the EU regulations, these regulations are not the first of their kind to deal with redressing the challenges of conflict minerals. Secondly, the section engages with the USA regulations on conflict minerals. An understanding of the USA regulations helps to place the limitations of the EU regulations in proper perspective. Notably, by drawing inspiration from the consequences of the implementation of the USA regulations, the section highlights the unintended human rights violations that could result from the rigorous implementation of the EU regulations. Moreover, the fact that the USA framework profoundly inspired the EU regulations, recourse to them becomes all the more worthwhile. Thirdly, the section discusses the EU regulations, clearly demonstrating the limitations of these regulations in addressing the ills of conflict minerals. It concludes that though they constitute a step in the right direction, at least according to some commentators, they establish a weak framework for the protection of human and environmental rights in the conflict-affected areas of Africa. 


\subsection{Other General Initiatives and Suggestions over and above the EU Regulations}

One of the arguments consistently advanced in this article is that some of the products consumed by individuals across continents could very much be fuelling armed conflict and human rights violations in Africa. Not surprisingly, over the years, various initiatives have been suggested and adopted to respond to this challenge, and to arguably provide redress to conflicts and human rights violations in Africa. This subsection briefly discusses some of these initiatives with a view to placing the discussion in broader perspective and demonstrating that the USA and EU regulations are not the first of their kind to respond or make suggestions regarding redressing this challenge.

From a scholarly point of view, some commentators have considered the possibility of the development of an international instrument fully devoted to redressing the conflictmineral conundrum. In Bannon and Collier's (2003) view, this instrument would focus on ideal management of natural resources. States endowed with natural resources would voluntarily subscribe to it. Based on this subscription, states would demand that international or multinational corporations furnish reports on the extent to which their operations measure up to acceptable governance of natural resources. Corporations would furnish these reports to either the general public or to independent international organisations such as the International Monetary Fund. At the national level, extractive companies operating in states that have subscribed to the international instrument would equally demand reports from these companies. As the case is for international corporations, the reports would be furnished to the general public or independent body. In Bannon and Collier's view, therefore, a binding international treaty should remain on the agenda of any discussions pertaining to the issue of conflict minerals.

At the regional level, commitment to redress this challenge can be gleaned from the initiatives of partnerships such as the New Partnership for Africa's Development (NEPAD). NEPAD was launched in 2001 by the Organisation of African Unity (now the African Union). As the name suggests, the partnership is aimed at advancing sustainable development across member states of the African Union (NEPAD 2001). Although NEPAD's framework does not explicitly mention conflict minerals, a close scrutiny of its aims and objectives does suggest that due regard is accorded to responsible behaviour as far as natural resource exploitation in Africa is concerned. Notably, the partnership aims, amongst others, to "harmonise policies and regulations to ensure compliance with minimum levels of operational practice" (NEPAD 2001). The foregoing objective can be progressively interpreted to encompass due diligence by business corporations in so far as conflict minerals are concerned. Recourse to conflict minerals would arguably be at odds with objectives such as this. NEPAD has also developed a number of initiatives on the protection of the environment. In the foregoing regard, the document establishing the NEPAD recognises the necessity of peace and security as conditions for sustainable development, and implores African states to build their capacity to prevent, manage and resolve conflicts and to pursue post-conflict reconstruction (NEPAD 2001). The Action Plan of the Environment Initiative of the NEPAD also acknowledges that armed conflicts on the African continent have resulted into considerable damage to the ecosystem as well as loss of biodiversity (NEPAD 2003). NEPAD (2003) also observed that armed conflict posed a significant threat to invaluable forest resources in Africa. Considered together, therefore, the NEPAD initiatives, at least implicitly, are aware of the need to address challenges surrounding the issue of conflict natural resources.

Beyond the African continent, mention can be made of the Organisation for Economic Cooperation and Development (OECD). The OECD is an intergovernmental organisation of 36 member states. ${ }^{5}$ Over the years, the OECD has developed frameworks geared towards advancing responsible behaviour concerning companies. An example is the OECD Due Diligence Guidance for Responsible Supply Chain of Minerals from Conflict-Affected

\footnotetext{
5 See the Organisation for Economic Cooperation and Development (OECD) website at http:/ / www.oecd.org/about/ (accessed on 10 May 2021).
} 
and High-Risk Areas. ${ }^{6}$ The OECD framework, amongst others, implores companies "to identify, prevent and remedy any infringement of human rights caused by their activities". In addition, the OECD Guidelines for Multinational Enterprises, though not specific to the issue of conflict minerals, underscore the need for companies to conduct due diligence in several areas including environmental ones. ${ }^{7}$ The practicality of these initiatives and suggestions remains far from clear and this issue is beyond the scope of the present discussion. What is clear though is that these initiatives constitute evidence of ongoing calls to redress conflict mineral-related challenges.

\subsection{The USA Law}

To avoid contributing directly or indirectly towards the commercialization of minerals from conflict-affected areas, the USA enacted Section 1502 of the Dodd-Frank Wall Street Reform Act. This section came into force in 2010. Given the rampancy of conflict and the human rights violations surrounding the issue of conflict minerals, the idea behind Section 1502 was to intercept the flow of funding to armed groups. ${ }^{8}$ Ideally, this would reduce the human suffering of civilians resulting from the violence perpetrated by armed groups in situations of conflict, and as one commentator crudely puts it, the idea is that Section 1502 would "cut off funding to people who kill people" (Parker 2018). Section 1502 of the Act places an obligation on companies that source tungsten, tin, tantalum, and gold from the DRC (and adjoining countries) to exercise due diligence. They are to disclose the source of their minerals and this disclosure is to be made to the USA Security and Exchange Commission (SEC) (Dodd-Frank Act 2010, sct. 1502). Suffice it to reiterate that these minerals are key components in the manufacture of products such as electronic devices, cameras, phones, and tablets (Prendergast and Lezhnev 2009). With the apparently wide scope of products relying on these minerals, such an obligation would weigh heavily on companies such as Apple and Intel (which deal in electronics).

Section 1502 has been implemented vigorously and it is only recently (2017) that the House of Representatives in the USA enacted a law to repeal the section because of the unintended consequences the law has had on the DRC (Chemical Watch 2017). This section, however, remains active since the USA Senate has not ratified the law on its repeal. The status of Section 1502 notwithstanding, at the time of its enactment, it was warmly welcomed by several adherents (Flowers 2013). It was viewed as a landmark law in so far as addressing the challenges surrounding conflict minerals were concerned. Some commentators have even gone as far as to compare Section 1502 with other soft law initiatives on this cause, drawing the conclusion that the binding nature of Section 1502 makes it a more effective framework when compared to the voluntary regulations (Oeko-Institut 2017). Recommendations have therefore been made for voluntary regulations to be made binding (Oeko-Institut 2017). Nevertheless, drawing inspiration from the consequences of the rigorous implementation of Section 1502, could the effective implementation of the EU regulations lead to unintended consequences, including threatening the human rights of civilians in conflict-affected areas?

It is worth noting that a large percentage of the DRC's gross domestic product is from the mining and extractive industry (World Bank 2008). The implication is that any interruption in the flow of income from mining and extraction would impact negatively on the country's economy. It is beyond dispute that the passing of Section 1502 into law was well-intentioned, seeking, amongst others, to address the human suffering resulting

6 See the OECD Due Diligence Guidance for Responsible Supply Chain of Minerals from Conflict-Affected and High Risk Areas, available at https://www.oecd.org/corporate/mne/GuidanceEdition2.pdf (accessed on 10 May 2021).

7 See the OECD Guidelines for Multinational Enterprises, available at http:/ /www.oecd.org/investment/mne/1922428.pdf (accessed on 10 May 2021).

8 Notably, the text of Section 1502 of the Dodd-Frank Act reads in part as follows: 1502 (a) 'sense of congress on exploitation and trade of conflict minerals originating in the Democratic Republic of the Congo.- It is the sense of Congress that the exploitation and trade of conflict minerals originating in the Democratic Republic of the Congo is helping to finance conflict characterized by extreme levels of violence in the eastern Democratic Republic of the Congo, particularly sexual- and gender-based violence, and contributing to an emergency humanitarian situation therein, warranting the provisions of section 13(p) of the Securities Exchange Act of 1934, as added by subsection (b).' 
from the conflict in the DRC. Indeed, Section 1502 has ensured greater transparency by companies relying on these minerals in the USA (Green Research 2012; Lynn 2011). In fact, it has been argued that since the passing of Section 1502, there has been greater commitment to responsible business behaviour by companies in this field (Stoop et al. 2013; Seay 2012). Some commentators (e.g., Bloem 2018), however, disagree with this notion, and crudely put, they remain wary of the logic behind this law. To them, the law was misconceived as the drafters failed to appreciate the dynamics of mineral extraction in conflict areas. These commentators' concerns cannot be simply dismissed in light of some of the unintended consequences of this section. Reports suggest that this law has contributed to the suffering of millions of civilians in the DRC (Stoop et al. 2013; Seay 2012). As a starting point, a large section of civilians in the DRC relies heavily on the mining and extractive industry for their livelihood (Addaney et al. 2019). The challenge, therefore, is that with the passing of Section 1502 into law, several companies abandoned minerals from the DRC altogether (Stoop et al. 2013; Seay 2012; Bloem 2018). This was with a view to steering clear of the costs resulting from the hassle of conducting effective due diligence (Bloem 2018). Suffice it to say that Section 1502 did not intend, in any way, to bar companies from sourcing minerals from conflict zones in the DRC. The unintended consequence, however, has been for companies to avoid dealing with the DRC altogether in as far as the sourcing of minerals is concerned. Without intending it, Section 1502 has turned out to be a de facto ban of companies from dealing with the DRC on issues of minerals, with American-based companies continuing to boycott minerals from the DRC.

The decrease in the demand for mineral resources from the DRC has left civilians with hardly any option but to engage in uncompetitive business (Stoop et al. 2013; Bloem 2018). This has negatively affected civilians' incomes and livelihoods. Reports have revealed that after the enactment of Section 1502, the price of minerals dropped significantly compared to the price of the same minerals on the global market (Raghavan 2014). Reports also reveal that the DRC's mineral exports have significantly reduced since the passing of Section 1502 (Stoop et al. 2013; Seay 2012; Bloem 2018). With the reduction in income levels, a number of rights have been threatened due to financial inaccessibility. Notable among these are health care and education. Many households can no longer afford basic services such as these (Parker et al. 2016). Parker et al. (2016) further reported that the infant mortality rate has spiked due to financial inaccessibility to health care services. The rampancy of learners' dropping out of school has equally been documented (Matthysen and Montejano 2013). Income reduction has also had a trickle-down effect, having the consequence of affecting other business sectors within the DRC's economy (Stoop et al. 2013; Seay 2012; Bloem 2018). Civilians in businesses such as tailoring, small-scale shops, local marketing, and hairdressing struggle to survive, as many civilians cannot afford to pay for these services (Stoop et al. 2013; Bloem 2018). For the thousands of civilians working in the mining and extractive industry, unemployment has become rife (Cuvelier et al. 2014). In this regard, Cuvelier et al. (2014) estimated that prior to Section 1502, the Artisanal mining sector supported thousands of miners because of the reliable flow of income. Nonetheless, with the decrease in the demand for minerals, the livelihood of these civilians was severely strained.

Even more appalling is the fact that with the decrease in funding, armed groups resorted to looting from the civilian population (Stoop et al. 2013). This is with a view to offsetting the burden resulting from their financial crisis. The change in tactics by these armed groups has come with a price, save that this price has not been paid by the enactors of Section 1502 but by civilians who continue to suffer the brunt violence taking multiple forms including murder and rape (Stoop et al. 2013). Considered together, therefore, these unintended consequences appear to be at odds with the overall aim of Section 1502, which was to reduce human suffering in the conflict area of the DRC. Does it therefore come as a surprise that the US House of Representatives has since passed a law, which if ratified by the US Senate, would repeal Section 1502? Perhaps not; it does appear, arguably so, that the human suffering resulting from Section 1502 is worse than 
the guilt resulting from consuming products resulting from conflict minerals. It is to be emphasised cautiously that the authors of this article do not, even remotely, seek to advance the view that companies should loom large and rely on minerals obtained through conflict and human rights violations. Far from it. Rather, it is to underscore that the rigorous implementation of mechanisms such as Section 1502 and the EU regulations could have unintended consequences. These mechanisms could, in fact, perpetrate human rights violations and ultimately undermine the initial aim of addressing human suffering. The narrative could be taken to its logical conclusion, the argument being that the drafters of these laws are indirectly perpetrating human rights violations due to the unintended human rights violations resulting from the passing of these frameworks. Drawing inspiration from the US, the EU has recently adopted regulations on conflict minerals. The question arises, could the EU regulations have better prospects for Africa? The answer to this question is provided in the next subsection.

\subsection{The 2017 EU Regulations: A Solution to Africa's Conflict-Resource-Related Challenges?}

The 2017 EU regulations on conflict minerals were profoundly inspired by the USA's 2010 Section 1502 of the Dodd-Frank Act. A few months after the enactment of Section 1502 , the EU started exploring the viability of adopting a similar framework. Thus, as early as October 2010, the EU started engaging in discussions on the adoption of a framework similar to the USA's, regarding the issue of conflict minerals. Unlike Section 1502, whose focus, in terms of jurisdictional scope, is the DRC, the EU considered opting for a framework that transcended the boundaries of the DRC, going as far as to cover all conflict-affected regions across continents.

The 2017 regulations, in their current form, are a slight departure from earlier proposals on this issue. In 2014, for example, the European Commission adopted a proposal on the responsible sourcing of minerals from conflict-affected areas. A peculiar feature of the 2014 proposed regulations was their non-binding nature. With a framework based on voluntariness on the part of EU-based companies, the idea was that the process of due diligence would entail self-certification by companies on their willingness to be bound by the regulations. Willing companies would self-certify that they were responsible importers. ${ }^{9}$ Due diligence on the part of these companies would entail ensuring that all their supply chains are not linked to any conflict or human rights violations. Loosely put, the 2014 regulations were non-binding, taking the form of persuasion on the part of EU-based companies to self-certify. While the proposed regulations were considered a positive step in the right direction, they were also the subject of withering criticism. In the words of Sargentini, a European parliament rapporteur on conflict minerals, with these regulations, the European Commission betted on a weak approach anchored in reputational damage. This, of itself, constituted "a neatly wrapped empty box" (The Guardian Support Network 2014). In the words of Pickles, a strong adherent for redressing conflict-mineral challenges, the regulations were "tantamount to the EU saying that it's ok for companies to choose not to behave responsibly" (Global Witness 2014). This, in her opinion, undermined the obligation on non-state actors including companies to protect human rights. Some commentators, in fact, vouched for a framework similar to the USA's Section 1502, which was binding and left no discretion to companies (Global Witness 2014). Amidst the contemptuous criticism against the 2014 regulations, the European Commission rethought its content.

In light of backlash resulting from the 2014 regulations, the 2017 regulations are of a binding nature on EU-based companies importing minerals from conflict-affected areas (see Article 1 of the $2017 \mathrm{EU}$ regulations). These regulations are to take effect in 2021. The lapse of time between 2017 and 2021 is to allow companies to become organized and to adjust their operations with a view to meeting the requirements of the regulations. The regulations will require EU-based companies that import gold, tungsten, tin, and tantalum

\footnotetext{
9 The 2014 regulation of the European Parliament and of the Council setting up a Union system for supply chain due diligence self-certification of responsible importers of tin, tantalum and tungsten, their ores, and gold originating in conflict affected and high-risk areas. See text of these regulations at https://trade.ec.europa.eu/doclib/docs/2014/march/tradoc_152227.pdf (accessed on 10 May 2021).
} 
into the EU to disclose whether their mineral supply is linked to conflict and human rights violations. This, the European Commission considered particularly pertinent because armed groups are in many instances in control of these minerals. It bears mentioning again that these minerals play a critical role in the production of a number of widely consumed products including jewellery, mobile phones, cameras, laptops, and other electronic devices. For a region such as Europe, the urgent need to adopt these regulations is perhaps less of a surprise in light of the available studies revealing Europe's level of consumption of these products. A 2009 study indicated that Europe is the second largest importer of electronics such as laptops and mobile phones in the entire world (European Parliament 2011). The $\mathrm{EU}$ is also a host of multiple companies relying on these minerals as raw materials (Gerber 2012). With this state of affairs, a strong and firm stance on responsible business behaviour could be far reaching, particularly in inspiring good practice amongst similarly situated companies in other regions.

There are a number of peculiar features in these regulations, some of which warrant mention in as far as redressing conflict and human rights violations in Africa is concerned. Notably, small quantities of the above-mentioned minerals are not covered by the 2017 regulations. Thus, small-scale businesses that utilize mineral imports from conflict affected are not under the obligations set out in these regulations and would, as such, be exempt from exercising due diligence. Moreover, the regulations only cover the above-mentioned four minerals. This means that other resources including water, timber and oil are excluded. Additionally, companies dealing in finished products such as jewellery, mobile phones and laptops are exempted from these regulations. Furthermore, companies further downstream from the importer, such as retailers and distributors, are not encompassed by the regulations. In terms of scope, as already alluded to, the regulations cover all conflict-affected areas. They are to be implemented by the EU member states' competent authorities. These regulations have been lauded as indicative of a new era of due regard for the rights of civilians in conflict-affected areas (Barbiere 2017). In the words of Winkler, a Romanian rapporteur on conflict minerals, with these regulations in place, "the vicious circle has now been broken. The interests of communities and people caught in war and conflict are our priority. The new Conflict Minerals Regulation has the power to improve reality on the ground in war zones" (Barbiere 2017). The question that remains unanswered, however, is: do these regulations constitute a strong, effective, and comprehensive framework for redressing conflict and human rights violations resulting from conflict minerals in Africa?

The answer to the above question is a resounding NO in light of the nature and scope of the 2017 regulations. Notably, the regulations target importers of minerals. The implication of this is that companies dealing in finished products effectively fall through the cracks of accountability. It is, therefore, very possible for these regulations to cause a shift in strategy on the part of companies. In this regard, companies could resort to importing finished goods as opposed to contending with the hassle of importing minerals. The importation of finished goods, however, does not change the fact that these finished goods could have relied on conflict minerals to produce finished goods. Moreover, as these regulations only apply to the EU region, importation of minerals and production could then start concentrating in non-EU regions, with the EU only receiving the unregulated finished goods. In addition, one could argue, persuasively so, that all that EU-based companies would need to do to escape these obligations would be to relocate to countries where these regulations are not applicable. However, this would be particularly unfortunate because, as already noted, the EU is one of the leading importers of products that rely on these minerals. Furthermore, placing emphasis on importers would also suggest that retailers and distributors would effectively escape liability and accountability. Moreover, nothing in the EU regulations stops armed groups from selling minerals to other non-EU regions. This state of affairs causes one to take a step back and to ponder: is it even practicable for a multi-faceted issue such as one on conflict natural resources to be addressed through a unilateral regulation, which applies to one region to the exclusion of other regions, whose cooperation remains pivotal in the enforcement of the regulations? 
Notable also is the fact that a certain threshold of conflict minerals remains acceptable in terms of the EU regulations. In this regard, small quantities of conflict minerals for small-scale businesses such as dentistry are exempt from the EU obligations. This, however, seems extremely problematic in light of the fact that the quantity of conflict minerals does not change the reality of these minerals having had links with conflict and human rights violations. Moreover, a question arises: how "small" is "small"? Would conflict minerals still fall within the ambit of "small" if, for example, thousands of small-scale businesses were sourcing from conflict-affected areas? Arguably not, because of the saying that goes "one by one makes a bundle." It is against this backdrop that the authors contend that such a stance is fundamentally flawed and in fact a gateway for human rights violations because these small-scale businesses, joined together, are capable of financing armed groups. Of course, the assumption is that when companies fail to comply, they are exposed through "name and shame" (Stork 2016). As such, consumers would be skeptical of supporting such businesses. However, even assuming this is the case, the real question is how many consumers care to know about the origins of the raw material for the products they consume.

Another issue of concern is the scope of natural resources covered by the regulations. The 2017 EU regulations, without equivocation, encompass gold, tin, tungsten, and tantalum. Clearly, this list is not only thin but also challenging to understand. With the wide range of minerals at the centre of conflict and the operations of armed groups in Africa including copper, silver, diamond, and lead (Osikhena 2009), the EU list is hard to fathom. Particularly notable is the fact that some of these excluded minerals form part of the EU's imports. ${ }^{10}$ Moreover, when mention is made of natural resources, clearly this transcends minerals. Various natural resources come into play including oil, timber, and water. These resources have been used to finance armed conflicts in Africa and ultimately contributed to unprecedented human rights violations (Verbelen 2002), and yet they fall outside the scope of the 2017 regulations on conflict natural resources. It is also pertinent to note the fact that these other natural resources falling outside the scope of EU regulations could suggest that armed groups can now shift focus from tin, tantalum, tungsten, and gold to reliance on other resources including water, timber, and oil to fund their activities. This is quite problematic as the overexploitation of these resources could further threaten the environment and even cause environmental degradation. If anything, it would defeat the overall aim of depriving armed groups of funding with a view to weakening their operations. These are real concerns because they touch on the fundamental rights of the African civilian population. Exposing these other resources to exploitation by armed groups could also risk the livelihood of many, including indigenous communities, which depend on them for survival. Thus, the EU and USA cannot just wish these realities away.

\section{Conclusions}

This article analysed the $2017 \mathrm{EU}$ regulations in light of similar regulations such as the USA's Section 1502. It assessed whether these regulations form an effective normative framework for realising the dated objective of protecting human rights in resource-driven conflict situations in Africa. The discussion in this article, of course, is far from being exhaustive. However, the overarching point is that frameworks such as the EU regulations constitute a weak normative framework for redress of the conflict mineral challenges. The brief analysis of the USA framework has also revealed the unintended consequences of rigorous frameworks. The discussion highlighted the unintended human rights violations resulting from their enforcement. The EU is not following so far behind and has very recently adopted regulations of a similar nature and one is curious to see how their implementation starting in 2021 plays out. The unintended consequences aside, a critical analysis of the EU regulations leaves much to be desired in terms of effectiveness. What

10 For example, diamond is excluded from the list of encompassed minerals under the $2017 \mathrm{EU}$ regulations. How realistic is this in light of the multiple products in Europe directly benefiting from this mineral to manufacture products such as jewellery? 
can be garnered from the discussion thus far is that there are fundamental flaws in both the USA's and the EU's regimes of redress. The discussion in this section has no more than punctured holes in these two frameworks. This, however, should not be interpreted to mean that the conflict-mineral challenge should go on unabated. Rather, the point the authors advance is that in developing responses that do not take context into account, the end result is a weak framework of redress. For example, poverty remains a serious challenge in many developing countries in Africa. In some of these conflict-affected regions, income from mineral extraction remains pivotal in the realization of fundamental rights. Thus, to develop blanket mechanisms that do not accord due regard to this reality is to threaten the livelihood of civilians and undermine civilians' human rights, an outcome that is at complete odds with the overall aim of the adoption of these frameworks. The all-encompassing issue, however, becomes: what then should be done? The answer to this question is one warranting further and detailed research and one that falls beyond the scope of the present discussion. However, what one can gather is that it appears that both the EU and USA did not think critically about the unintended consequences of these frameworks. There seems to be a need for the development of mechanisms that strike a proper balance between redressing the conflict-mineral challenge and respecting the human rights of the civilian population.

Author Contributions: Conceptualization, M.A. and E.C.L.; data curation, M.A. and E.C.L.; writingoriginal draft preparation, M.A. and E.C.L.; writing - review and editing, M.A. and E.C.L. All authors have read and agreed to the published version of the manuscript.

Funding: This research received no external funding.

Institutional Review Board Statement: Not applicable.

Informed Consent Statement: Not applicable.

Data Availability Statement: Not applicable.

Conflicts of Interest: The authors declare no conflict of interest.

\section{References}

Addaney, Michael, Michael Gyan Nyarko, and Elsabe Boshoff. 2019. Protection of the environment and natural resources during armed conflict in Africa. Chinese Journal of Environmental Law 3: 85-115. [CrossRef]

Altman, S. L., S. S. Nichols, and J. T. Woods. 2012. Leveraging high-value natural resources to restore the rule of law: The role of the Liberia forest initiative in Liberia's Transition to Stability. In High-Value Natural Resources and Post-Conflict Peacebuilding. Edited by Päivi Lujala and Siri Aas Rustad. New York and London: Earthscan.

Amnesty International. 2013. Mining and Human Rights in Katanga, Democratic Republic of the Congo. pp. 21-22. Available online: https:/ / www.amnestyusa.org/files/afr620012013en.pdf (accessed on 10 May 2021).

Arimatsu, L., and H. H. Mistry. 2012. Conflict minerals: The search for a normative framework. International Law Programme Paper 1: $1-37$.

Autesserre, S. 2008. The Trouble with Congo: How Local Disputes Fuel Regional Conflict. (May/June) Foreign Affairs 94. Available online: http:/ / www.foreignaffairs.com/articles/63401/sÃ@Averine-autesserre/the-trouble-with-congo (accessed on 10 May 2021).

Bannon, I., and P. Collier, eds. 2003. Natural Resources and Conflict: What We Can Do. In Natural Resources and Violent Conflict: Options and Actions. Washington, DC: The Word Bank.

Barbiere, C. 2017. Parliament Adopts Binding Law on Conflict Minerals. Available online: https://www.euractiv.com/section/ development-policy/news/parliament-adopts-binding-law-on-conflict-minerals/ (accessed on 10 May 2021).

Beevers, M. D. 2015. Governing natural resources for peace: Lessons from Liberia and Sierra Leone. Global Governance 21: 227-46. [CrossRef]

Beevers, M. D. 2018. Environmental peacebuilding in Liberia. In Routledge Handbook of Environmental Conflict and Peacebuilding. Edited by Ashok Swain and Joakim Öjendal. New York and London: Routledge.

Berman, N., and M. Couttenier. 2015. External shocks, internal shots: The geography of civil conflicts. Review of Economics and Statistics 97: 758-76. [CrossRef]

Bloem, J. R. 2018. Good intentions gone bad? The Dodd Frank Act and conflict in Africa's Great Lakes Region. Available online: https://jeffbloem.files.wordress.com/2018/05/term-paper.pdf (accessed on 10 May 2021).

Brown, C. 2011. Rape as a weapon of war in the Democratic Republic of the Congo. Human Rights Quarterly 33: 25-37. 
Chemical Watch. 2017. US House Passes Bill That Would Repeal Conflict Minerals Rule. Available online: https://chemicalwatch. com/56774/us-house-passes-bill-that-would-repeal-conflict-minerals-rule (accessed on 10 May 2021).

Coakley, G. J. 2000. The mineral industry of Congo (Kinshasa). In U.S. Geology Survey Minerals Yearbook; Washington, DC: U.S. Department of the Interior.

Benjamin Coghlan, Pascal Ngoy, Flavien Mulumba, Colleen Hardy, Valerie Nkamgang Bemo, Tony Stewart, Jennifer Lewis, and Richard Brennan. 2007. Mortality in the Demographic Republic of Congo: An Ongoing Crisis. International Rescue Commission. Available online: http:/ / www.rescue.org/sites / default/files/migrated/resources/2007/2006-7_congomortalitysurvey.pdf (accessed on 10 May 2021).

Cuvelier, J., S. Van Bockstael, K. Vlassenroot, and C. Iguma. 2014. Analyzing the impact of the Dodd-Frank Act on Congolese livelihoods. Conflict Prevention and Peace Forum 17: 1-33.

Davis, L., and P. Hayner. 2009. 'Difficult Peace, Limited Justice: Ten Years of Peacemaking in the DRC' International Center for Transitional Justice. Available online: http://www.ictj.org/static/Africa/DRC/ICTJDavisHayner_DRC_DifficultPeace_pa2009. pdf (accessed on 10 May 2021).

Dodd-Frank Act. 2010. Section 1502 of the United States of America Dodd-Frank Wall Street Reform and Consumer Protection Act (Hereinafter Dodd-Frank Act).

Enough Project and Grassroots Reconciliation Group. 2009. A Comprehensive Approach to Congo's Conflict Minerals. Available online: http:/ / www.enoughproject.org/files/publications/Comprehensive\%20Approach\%20to\%20Congo \T1 ttextquotelefts\% 20Conflict\%20Minerals.pdf (accessed on 10 May 2021).

European Parliament and of the Council. 2017. Regulation (EU) 2017/821. May 17. Available online: https://eur-lex.europa.eu/legalcontent/EN/TXT/PDF/?uri=CELEX:32017R0821\&from=EN (accessed on 10 May 2021).

European Parliament. 2011. Directorate-general for external policies of the Union. Available online: http:/ /www.europarl.europa.eu/ RegData/etudes/etudes/join/2011/433861/EXPO-INTA_ET(2011)433861_EN.pdf (accessed on 10 May 2021).

Fishman, J. L. 2005. Is diamond smuggling forever? The Kimberley Process Certification Scheme: The first step down the long road to solving the blood diamond trade problem. University of Miami Business Law Review 13: 224-25.

Fitzpatrick, C., E. Olivetti, T. R. Miller, R. Roth, and R. Kirchain. 2015. Conflict minerals in the computer sector: Estimating extent of tin, tantalum, tungsten, and gold use in ICT Products. Environmental Science and Technololgy 49: 974-81. [CrossRef]

Flowers, J. W. 2013. A Welcome Bright Spot in Africa and Human Rights Law. Available online: https://www.motleyrice.com/ blogpost/africa-human-rights-law (accessed on 10 May 2021).

George, S. 2013. Conflict Minerals: What Can the Mining Industry Do, The Guardian (15 May). Available online: http://www. theguardian.com/sustainable-business/conflict-minerals-mining-industry (accessed on 10 May 2021).

Gerber, L. 2012. Africa and the EU mineral trade. Polinares Working Paper Series 77. [CrossRef]

Global Witness. 2002. Logging Off: How the Liberian Timber Industry Fuels Liberia's Humanitarian Disaster and Threatens Sierra Leone. London and Washington, DC: Global Witness.

Global Witness. 2013. Breaking the Links between Natural Resources and Conflict: The Case for EU Regulation. Available online: http:/ / www.globalwitness.org/sites/default/ files/library/BreakingtheLinksENG.pdf (accessed on 10 May 2021).

Global Witness. 2014. Proposed EU Law Will Not Keep Conflict Resources out of Europe, Campaigners Warn (5 March). Available online: https:/ / www.globalwitness.org/en/archive/proposed-eu-law-will-not-keep-conflict-resourcesout-europe-campaignerswarn/ (accessed on 10 May 2021).

Grant, J. A. 2012. The Kimberley Process at Ten: Reflections on a Decade of Efforts to End the Trade in Conflict Diamonds. In High-value Natural Resources and Post-conflict Peacebuilding. Edited by P. Lujala and S. A. Rustad. New York: Earthscan, pp. 159-79.

Green Research. 2012. The Costs and Benefits of Dodd-Frank Section 1502: A Company-Level Perspective. Kelowna: Green Research Publishers.

The Guardian Support Network. 2014. EU Draft Law on Conflict Minerals Fails to Satisfy Campaigners (4 March). Available online: https: / / www.theguardian.com/global-development/2014/mar/04/eu-draft-law-conflict-minerals (accessed on 10 May 2021).

Henriksson, G., and M. B. Rivera. 2014. Why do we buy and throw away electronics? Paper presented at 20th Annual International Sustainable Development Research Conference, Trondheim, Norway, June 18-20; pp. 509-17.

Human Rights Commission of Sierra Leone. 2012. Report of the Public Inquiry into Alleged Human Rights Violations in Bumbuna, Tonkolili District in Relation to Events of 16-18 April. Available online: http://www.hrc-sl.org/PDF/Media/HRCSL\%20 Bubuna\%20Public\%20Inquiry\%20Report.pdf (accessed on 10 May 2021).

Human Rights Watch. 2018. Democratic Republic of Congo in Crisis. Available online: https://www.hrw.org/blog-feed/democraticrepublic-congo-crisis (accessed on 10 May 2021).

Institute for Environmental Security. 2008. Mining, Forest Change and Conflict in the Kivus, Eastern Democratic Republic of Congo. Available online: http://www.envirosecurity.org/espa/PDF/Mining_forest_change_and_conflict_in_the_Kivus.pdf (accessed on 10 May 2021).

International Rescue Commission. 2002. Mortality in the Democratic Republic of Congo: Results from a Nationwide Survey. SeptemberNovember. Available online: http:/ / www.rescue.org/sites/default/files/resource-file/2002-2003_Survey.pdf (accessed on 10 May 2021).

Keen, D. 2005. Conflict and Collusion in Sierra Leone. Oxford: Oxford University Press.

Kinzer, M. 2015. On the regulation of conflict minerals. University of Chicago Undergraduate Law Review 4: 89. 
Long, N. 2013. Map Shows Gold is Top Conflict Mineral in Eastern Congo, Voice of America (21 November). Available online: http:/ / www.voanews.com/articleprintview/1794975.html (accessed on 10 May 2021).

Lynn, D. M. 2011. The Dodd-Frank Act's specialized corporate disclosure: Using the securities laws to address public policy issues. Journal of Business and Technology Law 6: 327.

Maedl, A. 2011. Rape as weapon of war in the Eastern DRC? The victims' perspective. Human Rights Quarterly 33: 128-47. [CrossRef]

Matthysen, K., and A. Z. Montejano. 2013. Conflict Minerals' Initiatives in DR Congo: Perceptions of Local Mining Communities. Antwerp: International Peace Information Service, Available online: https:/ ipisresearch.be/publication/conflict-minerals-initiatives-drcongo-perceptions-local-mining-communities / (accessed on 10 May 2021).

Mitchell, Harrison. 2013. A Quick Update on a Possible EU Directive on Conflict Minerals. Available online: http:/ /www.rcsglobal $\mathrm{com} / \mathrm{blog}$ /a-quick-update-on-a-possible-eudirective-on-conflict-minerals / (accessed on 10 May 2021).

Murphy, S. K. 2010. Clouded diamonds: Without binding arbitration and more sophisticated dispute resolution mechanisms, the Kimberley Process will ultimately fail in ending conflicts fueled by blood diamonds. Pepperdine Dispute Resolution Law Journal 11: 221-22.

Murshed, S. M. 2014. New directions in conflict research from an economics perspective. In Conflicts over Natural Resources in the Global South-Conceptual Approaches. Edited by M. Bavinck, L. Pellegrini and E. Mostert. London: Taylor and Francis.

Nanda, V. 2014. Conflict minerals and international business: United States and international responses. ILSA Journal of International $\mathcal{E}$ Comparative Law 20: 285.

NEPAD. 2001. Strategic Framework of the New Partnership for Africa's Development, 37th Session of the Assembly of Heads of State and Government (NEPAD Strategic Framework). Abuja: African Union.

NEPAD. 2003. Action Plan of the Environment Initiative (2003): Para 133. Available online: http:/ /www.africa-platform.org/ sites / default/files/resources/9._vincent_oparah_nepad.pdf (accessed on 10 May 2021).

Nichols, J. E. 2012. A conflict of diamonds: The Kimberley Process and Zimbabwe's marange diamond fields. Denver Journal of International Law and Policy 40: 648.

O'Driscoll, D. 2017. Overview of Child Labour in the Artisanal and Small-Scale Mining Sector in Asia and Africa. Manchester: Knowledge, Evidence and Learning for development.

Oeko-Institut. 2017. Statement on the Draft Regulation of the European Commission on Minerals from Conflict-Affected Areas (17 March). Available online: https:/ / www.oeko.de/oekodoc/2002/2014-019-en.pdf (accessed on 10 May 2021).

Organisation for Economic Co-Operation and Development. 2013. OECD due Diligence Guidance for Reasonable Supply Chains of Minerals from Conflict-Affected and High-Risk Areas (OECD Due Diligence Guidance). Available online: http://www.oecd.org/ daf/inv/mne/GuidanceEdition2.pdf (accessed on 10 May 2021).

Osikhena, K. J. 2009. The Role of Diamonds in Sierra Leone History and Conflict: A Study Based on the West African Country Sierra Leone. Available online: https:/ / www.diva-portal.org/smash/get/diva2:369732/FULLTEXT01.pdf (accessed on 10 May 2021).

Palou, J. 2010. International Justice, Plunder in War, Human Rights and Multinationals. Barcelona: Ministry of Home Affairs.

Parker, D. 2018. Conflict Minerals or Conflict Policies? Property and Environment Research Center 37: 1.

Parker, D. P., and B. Vadheim. 2017. Resource Cursed or Policy Cursed? US Regulation of Conflict Minerals and Violence in the Congo. Journal of the Association of Environmental and Resource Economists 4: 1-49. [CrossRef]

Parker, D. P., J. D. Foltz, and D. Elsea. 2016. Unintended consequences of sanctions for human rights: Conflict minerals and infant mortality. Journal of Law and Economic 59: 731-74. [CrossRef]

Partzsch, L. 2018. The new EU conflict minerals regulation: Normative power in international relations? Global Policy 9: 1. [CrossRef]

Prendergast, J. 2009. Can you Hear Congo Now?: Cell Phones, Conflict Minerals, and the Worst Sexual Violence in the World. The Enough Project. Available online: http:/ / www.enoughproject.org/files/publications /Can\%20Your\%20Hear\%20Congo\%20Now. pdf (accessed on 10 May 2021).

Prendergast, J., and N. Atama. 2009. Eastern Congo: An Action Plan to End the World's Deadliest War. The Enough Project. Available online: http:/ / www.enoughproject.org/files/publications/eastern_congo.pdf (accessed on 10 May 2021).

Prendergast, J., and S. Lezhnev. 2009. From Mine to Mobile Phone: The Conflict Minerals Supply Chain. Washington, DC: Enough Project.

Raghavan, S. 2014. 'Obama's Conflict Minerals Law Has Destroyed Everything, Say Congo Miners' The Guardian, December 2. Available online: https:/ / www.theguardian.com/world/2014/dec/02/conflict-minerals-law-congo-poverty (accessed on 10 May 2021).

Rahima, A., S. Z. Safina, L. K. Khenga, N. Abasa, and S. M. Ali. 2016. Factors influencing purchasing intention of smartphone among university students. Procedia Economics and Finance 37: 245-53. [CrossRef]

Raj, S. 2011. Blood electronics: Congo's conflict minerals and the legislation that could cleanse the trade. Southern California Law Review 84: 981.

Ross, M. 2003. The natural resource curse: How wealth can make you poor. In Natural Resources and Violent Conflict: Options and Actions. Edited by I. Bannon and P. Collier. Washington, DC: The Word Bank.

Seay, L. E. 2012. What's wrong with Dodd-Frank 1502? Conflict minerals, civilian livelihoods, and the unintended consequences of western advocacy. Working Paper Series 284: 1-29. [CrossRef]

Shishmanian, A. 2012. World Gold Council Conflict-Free Gold Standard: An Introduction. World Gold Council. Available online: http: //www.srz.com/files/upload/ConflictMineralsResourceCenter/WorldGoldCouncilConflictFreeGoldStandard.pdf (accessed on 10 May 2021). 
Smillie, I., L. Gberie, and R. Hazelton. 2000. The Heart of the Matter: Sierra Leone, Diamonds and Human Security. Ottawa: Partnership Africa Canada.

Stoop, N., M. Verpoorten, and P. van der Windt. 2013. More legislation, more violence? The impact of Dodd-Frank in the DRC. PLoS ONE 13: e0201783. [CrossRef] [PubMed]

Stork, V. 2016. Conflict minerals, ineffective regulations: Comparing international guidelines to remedy Dodd-Frank's inefficiencies. New York Law School Law Review 61: 437.

Tegera, A. 2010. Impact of Presidential Mining Ban on Mining and Trading of Minerals in Eastern DR Congo, Good Electronics (29 October). Available online: http:/ / goodelectronics.org/news-en/impact-of-the-presidential-ban-on-mining-and-trading-ofminerals-in-the-eastern-dr-congo (accessed on 10 May 2021).

U.S. Department of State. 2010. Industry Representatives Discuss Conflict Minerals at the U.S. Department of State. May 14. Available online: http:/ / www.state.gov/r/pa/prs/ps/2010/05/141880.htm (accessed on 10 May 2021).

UN Environment Programme. 2010. Sierra Leone: Environment, Conflict and Peacebuilding Assessment. Nairobi, Kenya: UNEP.

UN Security Council. 2000. Res. S/RES/1306. Available online: https://undocs.org/en/S/RES/1306(2000) (accessed on 6 May 2021).

UN Security Council. 2003. Res. S/RES/1478. Available online: https:/ / undocs.org/S/RES/1478(2003) (accessed on 6 May 2021).

UN. 2011. DR Congo: UN Advises Prudent Use of Abundant Resources to Spur Development. Available online: http://www.un.org/ apps/news/story.asp?NewsID=39986\#.VGliSJPx178 (accessed on 10 May 2021).

Verbelen, F. 2002. Role of the African Timber Trade in the Creation of Conflict and Poverty-A Call for Action. Available online: http:/ / m.greenpeace.org/belgium/PageFiles/19005/timbrpov.pdf (accessed on 10 May 2021).

Woody, K. E. 2007. Diamonds on the Souls of Her Shoes: The Kimberley Process and the Morality Exception to WTO Restrictions. Connecticut Journal of International Law 22: 336-38.

World Bank. 2008. Democratic Republic of Congo Growth with Governance in the Mining Sector. Available online: https:// siteresources.worldbank.org/INTOGMC/Resources/336099-1156955107170/drcgrowthgovernanceenglish.pdf (accessed on 10 May 2021). 